This report was prepared as an account of work sponsored by an agency of the United States Government. Neither the United States Government nor any agency thereof, nor any of their employees, makes any warranty, express or implied, or assumes any legal liability or responsi- bility for the accuracy, completeness, or usefulness of any information, apparatus, product, or process disclosed, or represents that its use would not infringe privately owned rights. Reference herein to any specific commercial product, process, or service by trade name, trademark, manufacturer, or otherwise does not necessarily constitute or imply its endorsement, recommendation, or favoring by the United States Government or any agency thereof. The views and opinions of authors expressed herein do not necessarily state or reflect those of the United States Government or any agency thereof.

\title{
OIL FIELD GEOTHERMAL WATERS OF WYOMING
}

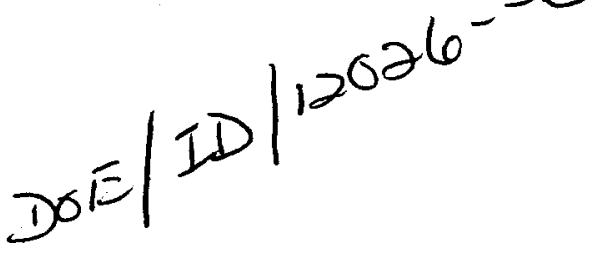

DOE/ID/12026--T3

Bern S. Hinckley

Work Performed under Cooperative Agreement

No. DE-FC07-79ID12026

for the

U. S. Department of Energy

August 1983

Wyoming Geothermal Resource Assessment Group

Department of Geology and Geophysics

University of Wyoming

Ltaramie, Wyoming 


\section{DISCLAIMER}

This report was prepared as an account of work sponsored by an agency of the United States Government. Neither the United States Government nor any agency Thereof, nor any of their employees, makes any warranty, express or implied, or assumes any legal liability or responsibility for the accuracy, completeness, or usefulness of any information, apparatus, product, or process disclosed, or represents that its use would not infringe privately owned rights. Reference herein to any specific commercial product, process, or service by trade name, trademark, manufacturer, or otherwise does not necessarily constitute or imply its endorsement, recommendation, or favoring by the United States Government or any agency thereof. The views and opinions of authors expressed herein do not necessarily state or reflect those of the United States Government or any agency thereof. 


\section{DISCLAIMER}

Portions of this document may be illegible in electronic image products. Images are produced from the best available original document. 


\section{Avallable from \\ National Technical Information Service \\ U.S Department of Commerce \\ 5285 Port Royal Road \\ Springfield, VA 22161 \\ NTIS Price Codes: Printed Copy A02 \\ Microfiche A01}

\section{DISCLAIMER}

This book was prepsred as an account of woth sponsored by an agency of the United states Government. Neither the United States Government nor any egency thereof, nor any of their employees, makes any warranty, express or implied, or assumes any bogal liablity or responsibility for the accuracy, completeness, or usefulness of any information, apparatus, product or process disclosed, or represents that fis use would not intringe privately owned rights. References herein to eny cpecific commercial product. process, or sarvice by trade name, trademark, manulacturer, or otherwise, does not necessarily constitute or imply its endorement, recommendation, or fevoring by the United States Government of any ageney thereot. The views and opinions of authors expressed herein do not nocessarily state or reflect those of the United States Government or any egency thereot. 


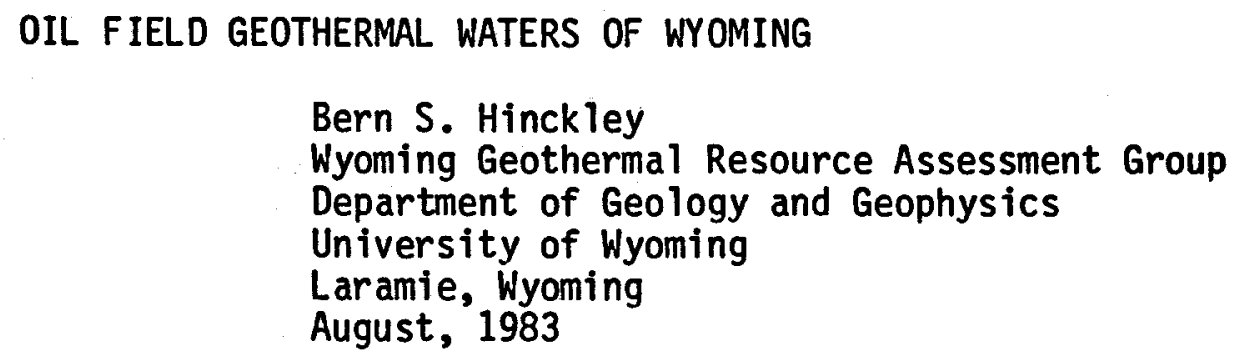

Introduction

Over 150 million gallons of water a day are brought to the surface in the oil fields of Wyoming. This water is produced for neither agriculture nor municipal use, but is a by-product accompanying the production of oil and gas. The temperature of this water is nearly always greater than $90^{\circ} \mathrm{F}$, and ranges as high as $230^{\circ} \mathrm{F}$. Approximately one half of the water is not reused by the oil and gas industry, but is disposed of either by reinjection or, more commonly, by discharge to the surface. The thermal energy of discharged water is simply dissipated, and the water either soaks into the ground or finds its way into natural drainages.

Fifty-two of the largest water producing oil fields in the state (accounting for over $98 \%$ of the total oil field water production) were inventoried in 1982 as the basis for this report. Eighty-eight percent of the water produced in these fields is warmer than $1000 \mathrm{~F} ; 60 \%$ is hotter than $1200 \mathrm{~F}$. If the total water production of these 52 fields were cooled to $70^{\circ} \mathrm{F}$, approximately 800 megawatts of thermal power would be released.

The purpose of this report is to briefly present the location, volume, temperature, and present use status of co-produced oil field thermal waters. It is hoped that making this information available will focus attention on development of applications for this substantial energy resource which, in spite of ready availability, is virtually unused at present.

Funding for this report was provided under cooperative agreement DE-F107791012026 between the U.S. Department of Energy and the University of Wyoming 
Department of Geology and Geophysics. The oil field operators contacted were in most cases very helpful and cooperative. Without their gracious assistance this report could not have been completed.

Geothermal Energy In Wyoming: Temperatures, Sources, Applications

As the overall limits of traditional energy supplies have become apparent, attention has increasingly focused on "alternative" energy sources such as geothermal. Since geothermal energy derives from the natural heat of the earth, it is dependent neither on past accumulations of organic material nor on the present, sun-powered systems of wind, water, or direct solar energy. Thus, the geothermal resource in general is uniquely stable, long-lived, and globally distributed.

The quality of this resource varies greatly, however. At the top of the scale are the spectacular hot springs and geysers of Yellowstone National Park and the 1000 megawatt geothermal stream electrical generating station at the Geysers, California. At the lower end, less impressive but much more widespread, is simply a warming of the earth with depth and an occassional warm spring.

The rate at which the earth warms up with depth (comonly expressed in of per 1000 feet of depth) is called the geothermal gradient. Geothermal gradients vary widely across the state of Wyoming as a function of heat flow, rock thermal conductivities, and hydrologic modifications. The nature, distribution, origin, and significance of subsurface temperatures are extensively evaluated in a series of reports by members of the Wyoming Geothermal Resource Assessment Group and will not be discussed here. For this report it is sufficient to note that normal geothermal gradients in Wyoming generally fall in the $11-160 \mathrm{~F} / 1000 \mathrm{ft}$. 
range. Since most $0 i 1$ and accompanying waters in Wyoming are produced from depths in excess of 5000 feet, the high temperatures encountered are not necessarily anomalous, but are the expected result of deep drilling. 0il well bottom-hole temperatures of $300^{\circ} \mathrm{F}$ or higher have been measured in most of the sedimentary basins of the state. The drilling depth required to reach these high temperatures, however, far exceeds that which can be economically justified by the hot water resource. Thus, the importance of oil fields is that oil and gas production pays well drilling and pumping costs and the produced geothermal waters represent a potentially valuable by-product.

Two critical parameters for geothermal development in Wyoming are the temperature and available quantity of geothermal waters. In Wyoming, thermal waters presently arrive at the surface via thermal springs, flowing wells, and along with oil and gas in oil and gas wells. Breckenridge and Hinckley (1978) cite a total flow of approximately 20,000 gallons per minute ( $\mathrm{gpm}$ ) of naturally occurring thermal water (excluding Yellowstone Park) with approximately $4500 \mathrm{gpm}$ in excess of $100^{\circ} \mathrm{F}$. Heasler et al. (1983) have compiled a partial list of important flowing thermal wells with a total flow of $20,000 \mathrm{gpm}, 18,000 \mathrm{gpm}$ over $100^{\circ} \mathrm{F}$. In comparison, the 1981 water production of Wyoming oil fields averaged $110,914 \mathrm{gpm}(178,918 \mathrm{acre} \mathrm{ft} / \mathrm{yr})$ (Petroleum Information Corp., 1981), with approximately $97,000 \mathrm{gpm}$ in excess of $100^{\circ} \mathrm{F}$.

Uses for Wyoming thermal waters are as varied as the temperatures. While it is doubtful the type of dry stream-turbine electrical system used at the Geysers, California, will ever be developed in Wyoming, there are technologies for using $180^{\circ} \mathrm{F}$ and warmer waters to produce electricity through more complex turbine cycles. This represents the high end of potential geothermal energy use in Wyoming and is of doubtful economic viability at that. More widely 
applicable uses fall generally into the categories of space conditioning and agricultural and industrial processing. Above approximately $170^{\circ} \mathrm{F}$ geothermal waters may provide energy to cooling and air conditioning cycles. Geothermal waters may simply replace the boiler-heated water of conventional heating systems down to $130-140^{\circ} \mathrm{F}$, and with adaptations, may provide useful direct space heating down to $80-90^{\circ} \mathrm{F}$. Through the use of groundwater heat pumps, energy can be economically extracted from waters as $\operatorname{cool}$ as $50^{\circ} \mathrm{F}$. Agricultural/industrial applications which have been successfully implemented in many areas of the world include greenhouse heating and agricultural product drying. Success has also been widespread in applying geothermal waters to the raising of fish and other aquatic food sources.

Basically, any energy use for which sub-boiling temperatures are adequate may be a potential application for Wyoming geothermal resources. The intention of this report is not to present an exhaustive list of these applications; the above discussion is provided simply to outline the possibilities. For an excellent treatment of the direct utilization of geothermal energy, including full discussion of the above, see Anderson and Lund (1979).

OIL FIELD THERMAL WATERS: MONITORING, LOCATIONS, VOLUMES, QUALITY TEMPERATURES, DISPOSITION

Monitoring

There is no systematic monitoring of oil field thermal waters in Wyoming at this time. The Wyoming 011 and Gas Conservation Commission maintains the largest data base on oil and gas activity in the state, including the water production reports from which Petroleum Information Corporation compiles their sumaries (see References). The 011 and Gas Commission also maintains cursory records (primarily cumulative volumes) on projects involving the injection of 
water into oil fields to maintain reservoir pressures. This water may be produced water, surface water, or groundwater developed specifically for this purpose.

Where produced waters are discharged to the surface, chemical characteristics and volumes are monitored at irregular intervals by the Water Quality Division of the Wyoming Department of Environmental Quality. Both the $0 i 1$ and Gas Commission and the Department of Environmental Quality are becoming involved in the regulation and monitoring of water injected simply for disposal. All waters in the state are also under the jurisdiction of the Wyoming State Engineer. Where waters are considered to be beneficially used, as in reinjection for pressure maintenance, water appropriation permits are required. Produced waters which are not used in this way, are considered by the State Engineer only beyond the point at which they may contribute to the flow of existing natural streams.

None of the agencies cited above gathers data on water temperature. (If the temperature of discharged waters were high enough to be a significant environmental concern, the Department of Environmental Quality is empowered to regulate such discharges.) Therefore, it has been necessary to contact ofl field operators directly for the information of this report. Information on water production, temperature and disposition is that provided by the operators unless otherwise noted. The essence of this report is assembled in Table 1. The discussion which follows is an explanation and discussion of the Table and proceeds on a column by column basis, including notes on table format and interpretation.

County/Location/Field. Due to the modest temperature of geothermal waters in Wyoming, most applications need to be near the point of avallability, and location is therefore an important constraint. The Salt Creek field in Natrona 
County, for example, surrounds the town of Midwest and might contribute thermal energy to a wide variety of residential and commercial space heating systems, to industrial and perhaps agricultural processing applications, and to greenhouse and aquaculture projects supplying the readtly accessible markets in Midwest and Casper. The Lance Creek field in Niobrara County, in contrast, is in an area of very low population density and is therefore more restricted to application in processes not dependent on community development or local markets.

Operator. In most cases, operations of a single field have been taken over by a single operator. Where this is not the case, the operator (or operators) responsible for the preponderance of the water production are listed, followed by an asterisk.

Water Volume. 0il fields are generally defined on the basis of the geologic conditions creating a more or less continuous oil reservoir. Thus, field sizes will vary greatly as will the number of wells contributing to total production. Since the ofl/water production of many wells is commonly collected at oil separation facilities, thermal waters will be concentrated at various locations within each field. The total production figures listed do not reflect in-field distribution; how much water is actually collected at any one point will vary widely depending on specific field characteristics. All volumes are listed in gallons per minute $(\mathrm{gpm}) ; 1 \mathrm{gpm}=1.6 \mathrm{acre}-\mathrm{ft} / \mathrm{gr}$. Water production values enclosed by parentheses in Table 1 are average 1981 values calculated from Petroleum Information Corp. Production Summaries (see References); no reports were received directly from field operators in these cases.

Since the value of oil field geothermal resources is small relative to the petroleum resources, oil fields will continue to be managed for optimum oil and gas revenues. It is unlikely this will generally lead to optimum geothermal 
production as well, so geothermal applications will be largely dependent upon petroleum production stategies. The range in water production (based on monthly averages for all operators in the field) has therefore been compiled from the published Production Sumaries (see References). Fields with relatively constant water production are certainly the most attractive candidates for geothermal development; development would have to be carefully coordinated with field operators to establish a secure energy source in any case.

Water Temperature. The temperature of produced water will generally decrease from the bottom-hole temperature to the point of final disposition. Geothermal applications which follow oil-water separation processes and in-field water uses will have to depend on somewhat lower temperatures than will applications which can extract heat from produced waters before or during separation processes. It should also be noted that all the thermal energy in produced waters is not an unused by-product. In some fields these waters are used to provide energy to treater facilities, which is of course a geothermal application itself. While the main value of water reinjected to enhance oil recovery derives from the simple pressure of the water, temperature may be of some benefit in terms of altering ofl viscosity and mobility.

Water Quality. The chemical quality of oil-field waters is generally quite poor. For space heating applications this may not be a significant problem if scaling and corrosion can be controlled. For agricultural/aquacultural applications, it may be necessary to use heat exchangers to transfer thermal energy to waters of more acceptable chemistry.

Water Disposition. Water produced with oil and gas is disposed of in one of three ways: 1) It may be discharged to the surface to either soak in, evaporate, or run into natural drainages; 2) It may be reinjected into an 
acceptable formation via waste disposal wells; 3) It may be reinjected into oilproducing strata to improve reservoir drive mechanisms and so to enhance oil recovery.

Water discharged to the surface is clearly the most readily available for geothermal development. Once waters enter a surface drainage they are no longer under the control of the field operator, but are regulated like any other surface water through the Wyoming State Engineer's Office. Heat is recognized as a beneficial use of water in Wyoming and can therefore justify a water appropriation. In many cases discharged oilfield waters are presently used for stock watering and irrigation. Where such uses have appropriated water rights they would take precedence over geothermal applications in the event of a conflict.

Question marks in the "Discharge Water" column of Table 1 indicate the partitioning of produced waters between the 3 options listed above is unclear. A question mark following a value indicates produced water was assumed to be surface discharged because there were no injection projects reported for these fields. Values enclosed by parentheses are taken from the files of the Water Quality Division of the Wyoming Department of Environmental Quality (DEQ). The number of discharge permits has also been extracted from these files. Numbers followed by an asterick denote permits which DEQ has noted as covering discharges greater than 1 million gallons per day (700 gallons/minute). Many discharge permits are filed against the contingency of possible discharge. Discharge may rarely occur under there permits, so the number of permits listed for a field is a maximum number of discharge points.

Second to waters discharged to the surface, the most available waters for geothermal applications are those destined for waste reinjection. These waters 
are presumably of no value to the $0 i 1$ and gas operations; examination of DEQ files reveals that in many cases waste waters which were previously surface discharged have been converted to reinjection due to tightening discharge water quality standards. Thus, geothermal applications which took over disposal of these waters would actually save the field operator the expense of reinjection. (Geothermal applications will, of course, themselves be subject to the same waste disposal regulations as any other water use.) As with the number of surface discharge points, the number of disposal wells reflects the degree of water concentration within the field. (The number of wells and formation data of Table 1 on both waste and enhanced recovery injection come from the Wyoming 0 il and Gas Conservation Commission (1980)).

of the three water disposition possibilities, waters used in enhanced recovery injection operations would be the most logistically difficult to utilize in geothermal applications. Depending on how the field operators view the value of temperature to the recovery processes, however, it may be possible to extract significant heat in "closed loop" processes which return the water for injection. While some portion of injected waters may cycle back through the system as produced water, this does not necessarily decrease their geothermal value. This recyling of cooled waters is an accepted way to usefully extract energy from very large subsurface heat sources.

Unlike the numbers of discharge permits or waste disposal wells, which represent the concentration of co-produced waters, the number of injection wells represents the dispersal of waters to create the proper injection pattern. The maximum concentrations of thermal waters in these fields will occur at separation facilities.

The "formations" involved in enhanced recovery operations are coded as follows: Ams - Amsden, Cam - Cambrian, Cur - Curtis, Dak - Dakota, Emb - Embar, 
๘

Fox - Fox HIlls, Fin - Frontier, Lan - Lance, Leo - Leo, Mad - Madison, Min Minnelusa, Mr - Morrison, Mst - Mesaverde, Mud - Muddy, Phi - Phosphoria, Shr Shannon, Sun - Sundance, Sis - Sussex, Ten - Tensleep.

$-10-$ 


\begin{tabular}{|c|c|c|c|c|c|c|c|c|c|c|c|c|c|c|c|c|}
\hline \multirow{2}{*}{ 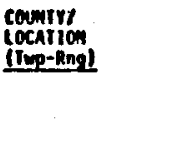 } & \multirow[t]{2}{*}{ Elfio } & \multirow[t]{2}{*}{ OPERATON } & \multicolumn{3}{|c|}{ Mire roune } & \multicolumn{2}{|c|}{ MaIER Remperntume } & \multirow{2}{*}{$\begin{array}{l}\text { matee quiltr } \\
\text { Totel ofssolved } \\
\text { Solids (ppm or } \\
\text { mg/il }\end{array}$} & \multirow[b]{2}{*}{$\begin{array}{l}\text { Dischor- } \\
\text { ged } \\
\text { yoter } \\
\text { lopni) }\end{array}$} & \multirow[b]{2}{*}{$\begin{array}{l}\text { Muber of } \\
\text { Oischarge } \\
\text { Pernits }\end{array}$} & \multicolumn{4}{|c|}{ Marea oisposing } & \multirow[b]{2}{*}{$\begin{array}{l}\text { Source } \\
\text { Forme- } \\
\text { tlon }\end{array}$} & \multirow[b]{2}{*}{$\begin{array}{l}\text { Forne- } \\
\text { tion- } \\
\text { Injer- } \\
\text { ted }\end{array}$} \\
\hline & & & $\begin{array}{l}\text { Meter } \\
\text { Production } \\
\text { (gpa) }\end{array}$ & 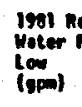 & 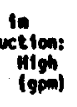 & 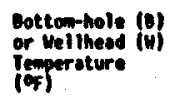 & $\begin{array}{l}\text { Injection (1) } \\
\text { of Discharge } \\
\text { (1) Tepper- } \\
\text { cure (of) }\end{array}$ & & & & $\begin{array}{l}\text { Moste } \\
\text { injected } \\
\text { Maler } \\
\text { gapon) }\end{array}$ & $\begin{array}{l}\text { Mumber of } \\
\text { olspostali. } \\
\text { Malls }\end{array}$ & $\begin{array}{l}\text { Mater Injected } \\
\text { fore Enhanced } \\
\text { Recovery (gpm) }\end{array}$ & $\begin{array}{l}\text { Mumber of } \\
\text { Active in- } \\
\text { jectlon } \\
\text { wellis }\end{array}$ & & \\
\hline Big. Homn & & & $T$ & & & & & & & & & & & & & \\
\hline ه9k-91W & Conenze & Conoco" & 303 & 290 & $m$ & $n \theta(w)$ & SO(D) & 1224 & 303 & 2 & -.. & $\cdots$ & $\ldots$ & $\cdots$ & $\cdots$ & -- \\
\hline $65,56 n-96,97$ & Ayrom & Morathon & 1121 & - & 1190 & $120-125(0)$ & $: \begin{array}{r}52-60101 \\
: 110-115(1)\end{array}$ & 3090 & 160 & 1 & $\cdots$ & $\cdots$ & 963 & 19 & Ten & Ten/Ento \\
\hline \multirow[t]{2}{*}{$65,56 \mathrm{n}-91,90 \mathrm{~W}$} & . Gorlend & Merotions & 6397 & 1132 & c9s2 & $(36-143(0)$ & $\begin{array}{c}20(0) \\
120-125(1)\end{array}$ & 3101 & 3360 & $3.1{ }^{\circ}$ & 1222 & 1. & 1016 & 24 & Ten & Ten/Phs \\
\hline & - & Texacot & 116 & & & $\rightarrow$ & $95(1)$ & 3996 & -.. & 2 & 118 & 2 & $\ldots$ & $\cdots$ & $\therefore$ & $\because \cdot$ \\
\hline $\begin{array}{c}4 m-91,90 w \\
\vdots\end{array}$ & Soge Creet & soln10* & 201 & 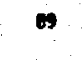 & 36 & scl(l) & co(1) & 3330 & $\cdots$ & 0 & $\cdots$ & -- & 287 & 2 & Ten & Ien \\
\hline $31 M-92,934$ & Torchlight & Amoce & 1750 & 1908 & 2059 & $\%$ & $\cdots$ & $\cdots$ & 1750 & 110 & -- & -- & $\cdots$ & $\cdots$ & $\cdots$ & $\cdots$ \\
\hline \multicolumn{17}{|l|}{ Compbell } \\
\hline $54 M-724$ & cos orom & cherron" & (1) & $m$ & 1264 & $182(1)$ & $150(11)$ & $\cdots$ & $\cdots$ & 0 & $\cdots$ & $\cdots$ & 67 & 15 & Foxnem & Ano \\
\hline $45 N-711 \mathrm{~W}$ & Milight & Inexco". & 2042 & 1760 & 2205 & $230(0)$ & $210(11)$ & $\ldots$ & $\cdots$ & 12 & $\cdots$ & $\cdots$ & 2012 & 38 & Fox & mot \\
\hline $40.49 m-69 \%$ & Moven Croet & mob11 & 369 & 157 & 390 & $135(\mathrm{~m})$ & 120111 & $\ldots$ & -- & D & $\cdots$ & $\cdots$ & 369 & 13 & Fox & min \\
\hline $56,57 M-69 N$ & Rocky Polnt & Amoco" & (940) & 1044 & 8325 & $\ldots$ & $115-127(0)$ & 2334 & (955) & $1 *$ & $\cdots$ & $\cdots$ & $\cdots$ & $\cdots$ & $\cdots$ & $\cdots$ \\
\hline SON:69,70n & Mazet & Arco" & 329 & 336 & 18 & $-\infty$ & $110-155(1)$ & $6,792-31,519$, & $\cdots$ & - & 323 & 1 & $\cdots$ & -- & $\cdots$ & $\cdots$ \\
\hline \multicolumn{17}{|l|}{ Carton } \\
\hline $211-79$ & $\begin{array}{l}\text { Big medielme } \\
\text { Bow }\end{array}$ & Mersethon & 217 & - & 3697 & $152(1)$ & $\cdots$ & 2497 & 211 & 1 & $\cdots$ & $\cdots$ & $\cdots$ & $\cdots$ & $\cdots$ & -.. \\
\hline $26 \mathrm{~N}-89,90 \mathrm{~W}$ & Mertz. & Anoco & 1058 & 428 & $31927^{\circ}$ & $105(0)$ & 135 & 10.404 & $m$ & 1 & $\cdots$ & $\cdots$ & 1450(7) & 27 & Ten/Mad & Ten \\
\hline \multicolumn{17}{|l|}{ Converse } \\
\hline $32.33 .34 \mathrm{~N}-75.76 \mathrm{~W}$ & $\begin{array}{l}\text { Souvk } \\
\text { Glenrock }\end{array}$ & conoces: & 510 & 590 & 736 & 120(II) & 100111 & 1333 & -- & 1 & $\cdots$ & $\cdots$ & $s 10$ & 59 & Mad/len & Mud/oak \\
\hline \multicolumn{17}{|l|}{ Fromont } \\
\hline $23,34 \mathrm{M}-96 \mathrm{M}$ & Deaver Creeth & Amoco & 115 & 255 & 626 & $230-234(0)$ & $90-140$ & 1975 & 240 & 2 & $\cdots$ & $\cdots$ & 467 & - & Mad & Mod \\
\hline 32W-95W & Dig sand or me. & Amoco & 3500 & 2849 & 5260 & 220111 & $135-170(0)$ & 2163 & 3500 & 3 & $\cdots$ & $\cdots$ & $\ldots$ & $\cdots$ & $\cdots$ & $\cdots$ \\
\hline $36,37 \mathrm{H}-8 \mathrm{ZW}$ & $\begin{array}{l}\text { Cosper creek } \\
\text { Morth }\end{array}$ & Kothermen & (241) & 0 & 311 & $\cdots$ & $\cdots$ & $\cdots$ & $244(1)$ & 1 & $\cdots$ & $\cdots$ & $\cdots$ & $\cdots$ & $-\cdot$ & $\cdots$ \\
\hline $6,7 w-2,3 n$ & circle creet & Conoce & 636 & - & 631 & $m(1)$ & 56 & 1768 & 563 & 2 & $\cdots$ & $\cdots$ & 73 & 10 & Ans & mass \\
\hline $201,92,934$ & Crooks sop & Amoco & 750 & 512 & $\mathrm{~ms}$ & $150(0)$ & $120(0)$ & 6466 & 758 & 1 & $\cdots$ & 1 & $\ldots$ & $\cdots$ & $\cdots$ & $\cdots$ \\
\hline $32 n-994$ & Dallos & union & 612 & - & 693 & $\cdots$ & $61-79$ & $\cdots$ & 612 & 1 & $\cdots$ & $\cdots$ & $\cdots$ & $\cdots$ & $\cdots$ & $\cdots$ \\
\hline $\begin{array}{l}33 \mathrm{M}-99 \mathrm{M} \\
25-1.2 \mathrm{E}\end{array}$ & Londer & Amoce & $3 n$ & 201 & 407 & $9(0)$ & $\theta(1)$ & $\cdots$ & $\cdots$ & 11 & $\cdots$ & -- & 379 & 26 & Pen & Phs \\
\hline Chl-2N & $\begin{array}{c}\text { Moverick } \\
\text { Springs }\end{array}$ & Crome- & (460) & III & 1853 & $\cdots$ & - & $-\cdots$ & $960(3)$ & 1 & $-\cdot$ & -- & $\ldots$ & $\cdots$ & $\cdots$ & $\cdots$ \\
\hline $4 n-14$ & $\begin{array}{l}\text { Stemboost } \\
\text { Butte }\end{array}$ & culf* & 17601 & 692 & $m 9$ & - & $99-154$ & $\cdots$ & 192 & $O(7)$ & $\cdots$ & $\cdots$ & 578 & $?$ & Ten/shs & Ten/mhs \\
\hline $2 n-1.24$ & Dintlemen & Mnoco* & 3159 & 243 & 3134 & (I5-220(D) & $100-180$ & $\cdots$ & 207 & 1 & $\cdots$ & $\cdots$ & 2952 & ss & Ten/Phs & Ten/phs \\
\hline \multicolumn{17}{|l|}{ Hot Springs } \\
\hline $42,433-914$ & Heck Ntm. & Texece & $m$ & 53 & 619 & - & 90 & 750 & $\cdots$ & 1 & 144 & 1 & $\cdots$ & $\cdots$ & $\cdots$ & $\cdots$ \\
\hline 44N-95W & Gebo & Conoce & 510 & - & 500 & $120(11)$ & $90(0)$ & $310 \%$ & 510 & 1 & $\cdots$ & $\cdots$ & $\cdots$ & $\cdots$ & $\cdots$ & $\cdots$ \\
\hline $46 n-964$ & Grass creet & Merathon & 3305 & 2721 & 3504 & $70-120(0)$ & $69-110(1)$ & 5279 & $\cdots$ & 6 & 343 & 1 & 2962 & 99 & Msymad & Cur/Fra/Te \\
\hline \multirow[t]{2}{*}{ 411-97,901 } & Menilitom & Ares & 3379 & 4154 & 1101 & $\cdots$ & $143(0)$ & 3565 & 3379 & $.1,1 *$ & $\cdots$ & $\cdots$ & $\cdots$ & $\cdots$ & $\cdots$ & $\cdots$ \\
\hline & & Petrotenls & 3103 & & & $96-124$ & $103(11), 5010)$ & 3520 & 2539 & $1,11^{\circ}$ & $\cdots$ & $\cdots$ & G45 & 21 & Ten/Phs & Phs \\
\hline $\begin{array}{l}43 M-91,92 W \\
47,48 M-99,100 \mathrm{~W}\end{array}$ & $\begin{array}{l}\text { Late Croet/min } \\
\text { Littlo Buffelo }\end{array}$ & $\begin{array}{l}\text { Sitty } \\
\text { Anoce }\end{array}$ & $\begin{array}{l}(405) \\
4181 .\end{array}$ & $\begin{array}{r}145 \\
3376\end{array}$ & $\begin{array}{r}110 \\
4322\end{array}$ & $110-120$ & $\cdots$ & $\cdots$ & $\begin{array}{l}\text { 205(1) } \\
233\end{array}$ & 11 & $\cdots$ & $\cdots$ & 3936 & $\ddot{110}$ & emo/ren & $\cdots$ \\
\hline
\end{tabular}




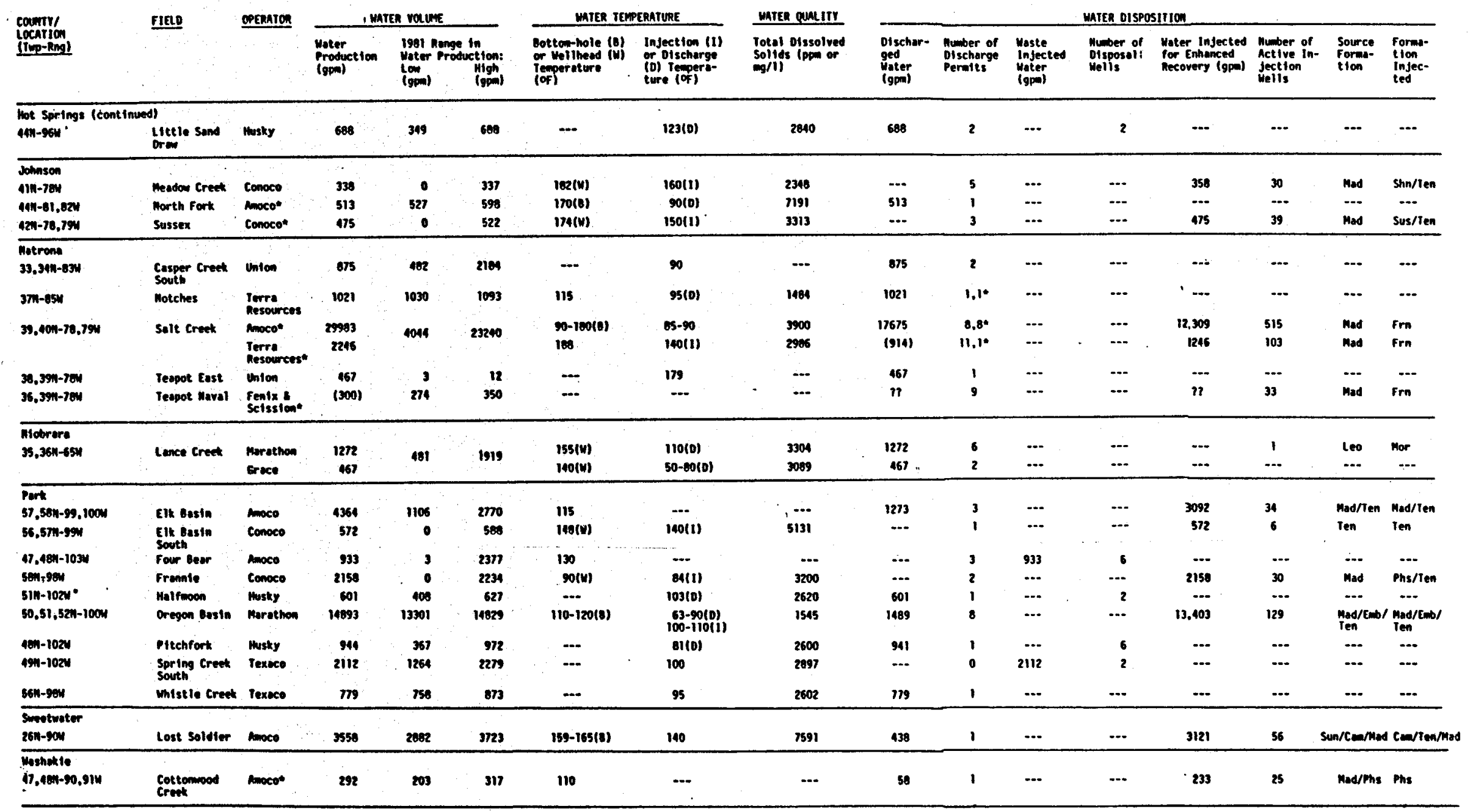


REFERENCES

Anderson, D.N. and J.H. Land, 1979, Direct Utilization of Geothermal Energy: A Technical Handbook, Geothermal Resources Council Special Report No. 7 (P.0. Box 98, Davis, CA 95616), 237 p.

Breckenridge, R.M. and B.S. Hinckley, 1978, Thermal Springs of Wyoming, Geological Survey of Wyoming, Bulletin 60, $104 \mathrm{p}$.

Heasler, H.P., 1982, The Cody Hydrothermal System, Thirty-third Annual Field Conference, Wyoming Geological Association Guidebook, pp. 163-174.

Heasler, H.P., K.L. Buelow, E.R. Decker, B.S. Hinckley, and S.A. Spencer, compiles, 1983, Geothermal Resources of Wyoming, 1:500,000 map (available from Geological Survey of Wyoming, Laramie, Wyoming, 82071).

Hinckley, B.S., H.P. Heasler, and J. King, 1982, The Thermopol is Hydrothermal System with an Analysis of Hot Springs, State Park, Geological Survey of Wyoming, Preliminary Report No. 20, 42 p.

Petroleum Information Corporation, 1981, Monthly 0 il and Gas Production Reports for Wyoming, Petroleum Information Corporation, Denver, Colo.

Wyoming 0 il and Gas Conservation Commission, 1980, Wyoming 0 il and GasStatistics, Wyoming 0 il and Gas Conservation Commission, Casper, Wyo., $118 \mathrm{p}$.

$-13-$ 